\title{
Solid waste management in rural areas nearby river Ganga at Haridwar in Uttarakhand, India
}

\author{
Ankur Rajpal* \\ Environmental Engineering Group, Civil Engineering Department, Indian Institute of Technology \\ Roorkee (IITR)-247667 (Uttarakhand), India \\ Absar Ahmad Kazmi \\ Environmental Engineering Group, Civil Engineering Department, Indian Institute of Technology \\ Roorkee (IITR)-247667 (Uttarakhand) India \\ Vinay Kumar Tyagi \\ Environmental Engineering Group, Civil Engineering Department, Indian Institute of Technology \\ Roorkee (IITR)-247667 (Uttarakhand), India \\ ${ }^{*}$ Corresponding author. Email: ankur.envt@gmail.com
}

\section{How to Cite}

Rajpal A. et al. (2020). Solid waste management in rural areas nearby river Ganga at Haridwar in Uttarakhand, India. Journal of Applied and Natural Science, 12(4):592 - 598. https://doi.org/10.31018/jans.v12i4.2394

\begin{abstract}
The solid waste found in rural areas can be used as a soil conditioner providing essential nutrients to crops and enhancing agricultural productivity. It is an eco-friendly and economic preference for Municipal Solid Waste Management (MSW). This study investigates the solid waste management scenario in rural areas along the river Ganga and proposes a sustainable waste management solution. Waste quantification and composition were determined in the five villages (rural areas) viz. Sajanpur, Shyampur, Kangri, Bhogpur and Dummanpuri of district Haridwar in Uttarakhand and their waste management and disposal systems were evaluated. Findings revealed that the average daily waste generation was $0.665 \mathrm{~kg} /$ day and per capita generation of household waste was around $0.16 \mathrm{~kg} /$ person/day. Major fraction of household waste was bio-degradable $(74.14 \%)$ and remaining fraction comprised of paper $(6.62 \%)$, polythene $(2.82 \%)$, textile $(2.52 \%)$, plastic $(1.15 \%)$, glass $(0.61 \%)$, metal $(0.60 \%)$, rubber $(0.35 \%)$, and inert $(5.01 \%)$. The average bulk density of household waste was $460 \mathrm{~kg} / \mathrm{m}^{3}$, whereas cattle waste bulk density was $834 \mathrm{~kg} / \mathrm{m}^{3}$. Other waste characteristics included moisture content $(60 \%)$, organic carbon $(40 \%)$, nitrogen $(1.7 \%)$, phosphorus $(0.9 \%)$ and ash $(31 \%)$. The calorific value of household waste (biodegradable) was $937.6 \mathrm{kcal} / \mathrm{kg}(\mathrm{dry}$ basis). Since most of the waste was biodegradable, hence co-composting with cattle waste is recommended. The dry waste can be separated and stored for further processing and transported to nearby waste to energy-producing plants. The main hurdle to the program of waste recycling was the unsegregated collection of waste in rural areas. Hence, separation at the source comprised biodegradable waste, dried waste (paper, plastic, and metal) and other components are essential for the future solid waste management program.
\end{abstract}

Keywords: Composting, Rural areas, Solid waste characterization, Solid waste management, Source-separation

\section{INTRODUCTION}

Presently, the amount of solid waste produced annually in the Indian towns has been found to be greater than before, i.e., from 6 million tons (1947) to 48 million tons (1997) besides the growth rate of $4.25 \%$ annually was observed. As reported by CPCB, 2004 that it is also estimated to enhance the quantity of waste to 300 million tons by 2047 (CPCB, 2004). In India, about $90 \%$ of MSW are nonstop disposed on the surface of the land in an inadequate way (Das et al., 1998). According to World Data Bank report (2015), nearly 3.3 billion $(46 \%)$ of the world's population and 0.83308 billion $(68.8 \%)$ of the Indian population is residing in the rural region. In the Indian villages, the houses are found in the central location, surrounded by the differ- ent types of land, i.e., agricultural land, pasture, and forest lands. In general, the family member in the Indian villages is 5-6 adult members and 4-5 numbers of cattle within each house. The residues of crop and domestic refuse (human excreta and kitchen waste) are the dominant wastes generated, most of which are piled on the land in an open yard, and compost is made away from the houses. The mixed smell of the decomposing human excreta and the smoke obtained from the incomplete burning of biomass fuels are the signs of better waste management in our villages. Several types of research have been published on urban solid waste characterization, its management, and treatment in various cities of both developed and developing countries. Simultaneously, significantly 
less information is available regarding the composition and management of rural domestic solid waste examples of the few studies have been reported on rural household solid waste such as El-Messery et al. (2009) in Egyptian rural communities, González et al. (2010) in Mexico, Dorenfeld et al. (2012) in cities of Namibian, Shah et al. (2012) in villages near Tekanpur in India, Mohammadi et al. (2012) in Iran Ogwueleka (2013) in rural area of Nigeria, Agamuthu et al. (2019) and Agamuthu et al. (2020). However, developing countries of Asia and Africa fail to receive attention in domestic solid waste management issue in the rural areas as compared to the urban areas. The appropriate management for the crop residues and the excreta obtained from the habitats of animals and humans in the rural areas is the need of the hour. Globally, less information is available about the solid waste generation and composition in the rural areas, especially in the northern region and along with the rural riverside community. Hence, in the absence of such information, the authorities of rural sanitation are incapacitated for designing and operating solid waste management in the cities.

Therefore, the micro-level characterization of solid waste generated in rural regions is necessary for designing waste management programs to prevent the harmful effects of untreated solid waste on public and environmental health and reduce economic losses. Also, there is an urgent need to manage solid waste in an eco-friendly and economically preferable mode in India's rural area. Overall, the present investigation will provide the MSW management scenario in the rural areas across the river Ganga and proposes a possible sustainable waste management solution.

\section{MATERIALS AND METHODS}

Study area: Haridwar city has over 1,890,422 (Census, 2011) and about $81 \%$ population live in villages (rural areas). The studied villages come under the peripheral distance $25 \mathrm{~km}$ from Haridwar city. During the study, out of the five villages, two villages- (V1) Bhogpur, (V2) Dummanpuri are on the west side bank while three villages - Shyampur (V3), Sajanpur (V4) and Kangri (V5) are on the eastern side bank of the river Ganga of district Haridwar in Uttarakhand were selected as shown in Fig. 1. A survey was carried out from September to November 2018 from the selected households in most of the areas in villages. Several visits were conducted to collect necessary information, population, assess working conditions, and evaluate the current state of waste management in all the selected villages under the aegis of Namami Gange scheme initiated by Govt. of India for the effective abatement of pollution, conservation and rejuvenation of National River Ganga. Table 1 shows the population of selected five villages of Haridwar city with a combined population of nearly 20,826 during the study.

Sample collection: A questionnaire was prepared by the research group of Environmental Engineering Section, Indian Institute of Technology Roorkee (IITR), and a survey was conducted door to door. The data was obtained regarding the quantity of MSW, disposal on a daily basis, container availability, frequency of collection and level of satisfaction, etc. Similarly, the per capita generation rate of MSW (kg/capita/day) was estimated from the sampled population of the villages during the survey. Finally, based on the data collection and analysis, the best suitable alternatives were found out for the waste management other than the landfilling process. A survey was conducted covering the solid waste produced every day. The standard procedure of sample collection and MSW analysis was adopted as defined in Peavy et al. (1985). In each of the selected five households, containers for waste collection corresponding to the number given to that household were placed at a specific location, under the observation of the house leader to manage the separation of their garbage into these containers. Containers and waste bags were labelled corresponding to the fraction of waste, i.e., organic fraction, plastic waste, paper, and metal waste. The regular collection was done two times a week during the investigation period (September to November 2018).

The waste generation rate was determined by combining the generated and collected waste. Waste was weighed every day and the physical composition of the solid waste was investigated. The solid waste collected was mixed thoroughly, and random sampling was performed. Waste was separated manually into food waste, cardboard and paper, plastics, metals, rubber, textiles, glass, woods, and other wastes such as inert wastes, construction debris, dirt, ash, etc. This group of wastes was weighed, and the outcomes were noted. A box made up of wood of $0.028 \mathrm{~m}^{3}$ was used to estimate the volume and the density of the waste onsite. The values were calculated in $\mathrm{kg} / \mathrm{m}^{3}$. Samples were collected in the polyethylene bags and transported for further physical and chemical examination to the Environmental Engineering Laboratory of Institute Roorkee IITR, India. These samples were analyzed for moisture content (according to wet weight). Thereafter, moisture content (APHA, 2012) was analyzed, and dried samples were ground and sieved through a $0.2 \mathrm{~mm}$ sieve.

Composite sampling: 1 to $2 \mathrm{~kg}$ amount of mixed waste sample depended on the generation from each home in each community was collected and transported to the processing site and for further investigation. Afterwards, six samples from each site were assorted properly. Finally, sub-samples of about $20 \mathrm{~g}$ were preserved into airtight beg and sent to the laboratory for further examination.

Physico-chemical characteristics: Physico-chemical parameters such as moisture content, bulk density, carbon, nitrogen, phosphorus, and potassium were analyzed. Moisture content was evaluated by the weight loss of the sample $\left(105^{\circ} \mathrm{C}\right.$ for $\left.24 \mathrm{~h}\right)$ as per the 


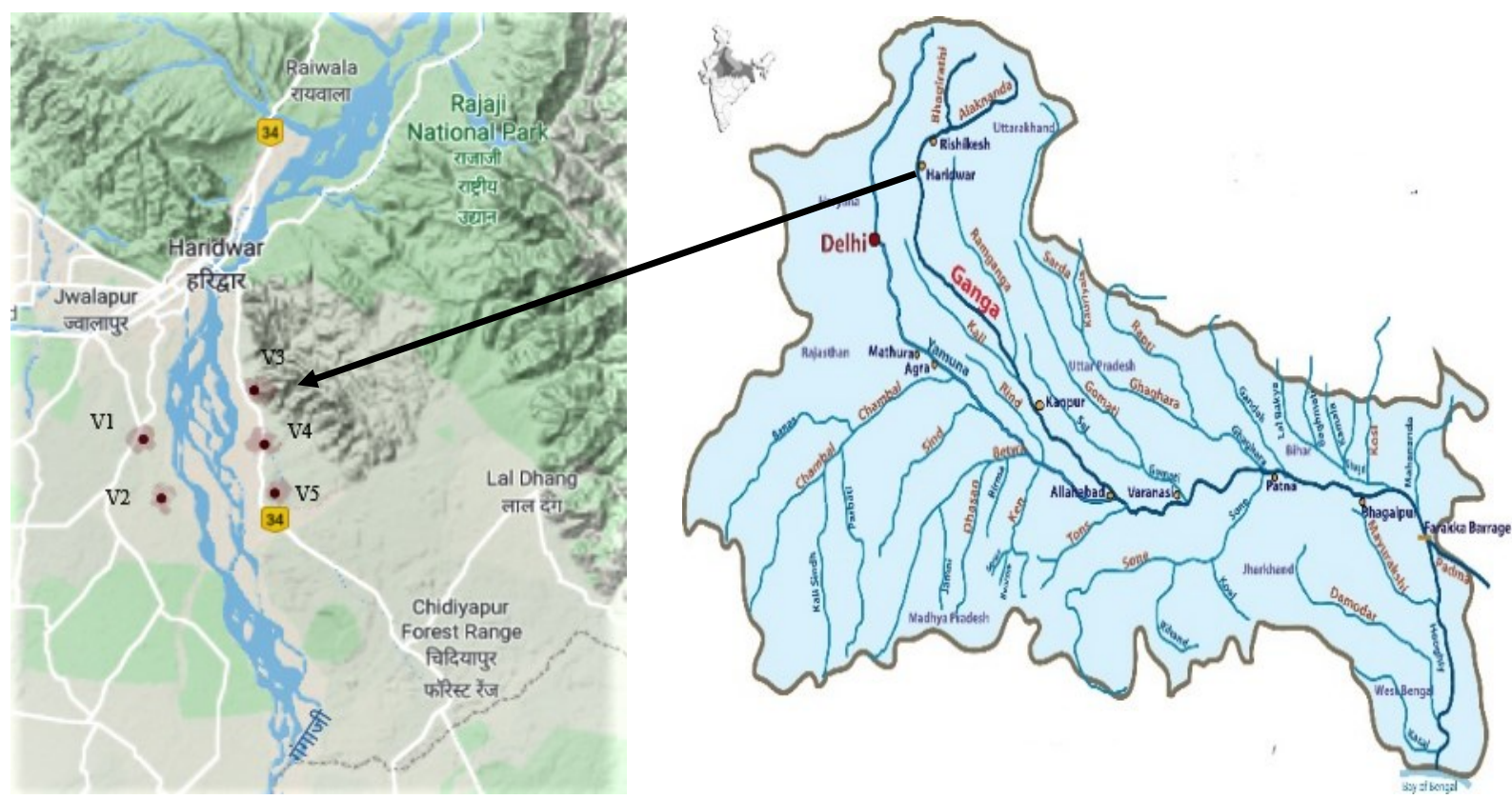

Fig. 1. Locations of villages in study site (V1) Bhogpur, (V2) Dummanpuri, (V3) Shyampur, (V4) Sajanpur and (V5) Kangri of District Haridwar (Source: Google map).

standard method APHA (2012). Carbon and nitrogen (\%) were detected on a dry matter basis by using Vario ELIII CHNSO elemental analyzer, phosphorus (acid digest) using the stannous chloride method, potassium detected using a flame photometer (Rajpal et al., 2014).

\section{RESULTS AND DISCUSSION}

Generation of waste: Waste generation rate measurement is the prerequisite to plan and design the program of any waste management. It is an important parameter to improve the practices of solid waste management (Dangi et al. 2011; Fahiminia et al. 2014). The quantity of the waste produced in studied five villages (Kangri, Shyampur, Sajanpur, Bhogpur and Dummanpuri) is detailed in Table 2 and Fig. 2. These five villages collectively generated 3.97 tons/ day and about 140.81 tons/day of household and cattle waste, respectively. Average individual household waste generation in studied villages, V-1, V-2, V-3, V-4 and $V-5$ was $651.4,495.6,445.9,1741.5$ and 639.3 $\mathrm{kg} /$ day. The generation of waste was highest in the $\mathrm{V}$ 4 , attributing to the largest population among the others. Results indicated that the average per capita of household waste generation rates in the five studied villages, namely $\mathrm{V}-1, \mathrm{~V}-2, \mathrm{~V}-3, \mathrm{~V}-4$ and $\mathrm{V}-5$ was about $0.22,0.20,0.19,0.18,0.19 \mathrm{~kg} /$ capita.day, respectively (Table 2). It was observed that the rate of waste generation in these rural areas was estimated to be lower as compared to the urban areas of average $0.5 \mathrm{~kg} /$ capita.day (CPCB, 2015).

Waste composition: Determination of solid waste composition is crucial for waste management to reduce, recycle, process and finally, disposal of solid waste (Tchobanoglous et al. 2002; Al-Khatib et al. 2010; Adeniran et al. 2017). The density and average composition of the solid waste generated by the five villages selected for the study are presented in Fig. 3a and $\mathrm{b}$. Waste composition analysis showed no significant difference among the studied communities. The density and moisture content of household waste ranged between $437.5-484.1 \mathrm{~kg} / \mathrm{m}^{3}$ and $60-63 \%$, respectively, in the studied villages (Fig. 2). Fig. 3 and Table 3 showed that about $70 \%$ to $80 \%$ of the total waste generated included organic and food waste in the studied sites. In contrast, various kinds of wastes such as paper waste, metals, plastics textiles, rubber, glass and woods comprised about 20 to $30 \%$ of the total generated waste. Observations reported that the generated waste included $10 \%$ recycling waste. Systematic separation of waste is essential for a successful integrated waste management system. The waste would be sorted at the source to reduce the large quantity of waste required to be disposed of. The techniques of sorting and reusing programs at the source are essential to reduce waste generation. From the results, it was observed that the high percentage of food waste and the organic content was the major component of the solid waste in the studied villages (Table 3) (Fahiminia et al. 2014; Ugwu et al. 2020). Hence, it is recommended that the techniques like pile composting and vermicomposting (Bhatia et al. 2011 and Rajpal et al. 2014) can be opted to reduce the disposal of waste generated in the rural areas. There was a noticeable difference between the study results and the observations reported earlier in other rural and urban areas, and significant variation was observed in the quantity and composition of solid 
Rajpal A. et al. / J. Appl. \& Nat. Sci. 12(4): 592 - 598 (2020)

Table 1. Population data of human and cattle population of selected five villages of district Haridwar.

\begin{tabular}{|c|c|c|c|c|c|}
\hline S. No & Name of Village & Area $\left(\mathrm{km}^{2}\right)$ & Co-ordinates & $\begin{array}{l}\text { Human Popula- } \\
\text { tion (2018) }\end{array}$ & $\begin{array}{l}\text { Cattle Population } \\
(2018)\end{array}$ \\
\hline 1 & V-1 (Bhogpur) & 3.58 & $29^{\circ} 46^{\prime} 56^{\prime \prime} \mathrm{N} 78^{\circ} 10^{\prime} 0^{\prime \prime E}$ & 2961 & 647 \\
\hline 2 & V-2 ( Dummanpuri) & 3.4 & $29^{\circ} 39^{\prime} 40^{\prime \prime} \mathrm{N} 78^{\circ} 5^{\prime} 17^{\prime \prime E}$ & 2478 & 2289 \\
\hline 3 & V-3 ( Shyampur) & 4.91 & $29^{\circ} 52^{\prime} 00^{\prime \prime} \mathrm{N} 78^{\circ} 10^{\prime} 57^{\prime \prime E}$ & 2347 & 474 \\
\hline 4 & V-4 ( Sajanpur) & 33.62 & $29^{\circ} 51^{\prime} 27.4^{\prime \prime} \mathrm{N} 78^{\circ} 12^{\prime} 7 " \mathrm{E}$ & 9675 & 3874 \\
\hline 5 & V-5 ( Kangri) & 8.25 & $29^{\circ} 53^{\prime} 48^{\prime \prime N} 78^{\circ} 10^{\prime} 25^{\prime \prime E}$ & 3365 & 539 \\
\hline
\end{tabular}

Table 2: Cattle and household waste generation in the selected villages during the study period (September to November 2018).

\begin{tabular}{lllll}
\hline S. No & Name of Village & $\begin{array}{l}\text { Cattle Waste } \\
\text { gen/day }(\mathbf{k g})\end{array}$ & $\begin{array}{l}\text { Household Waste } \\
\text { gen/day }(\mathbf{k g})\end{array}$ & $\begin{array}{l}\text { Per capita Waste } \\
\text { generation }(\mathbf{k g})\end{array}$ \\
\hline 1 & $\mathrm{~V}-1$ & 11646 & 539 & 0.192 \\
2 & $\mathrm{~V}-2$ & 41202 & 422 & 0.18 \\
3 & $\mathrm{~V}-3$ & 8532 & 416 & 0.189 \\
4 & $\mathrm{~V}-4$ & 69732 & 1403 & 0.151 \\
5 & $\mathrm{~V}-5$ & 9702 & 546 & 0.170 \\
\hline
\end{tabular}

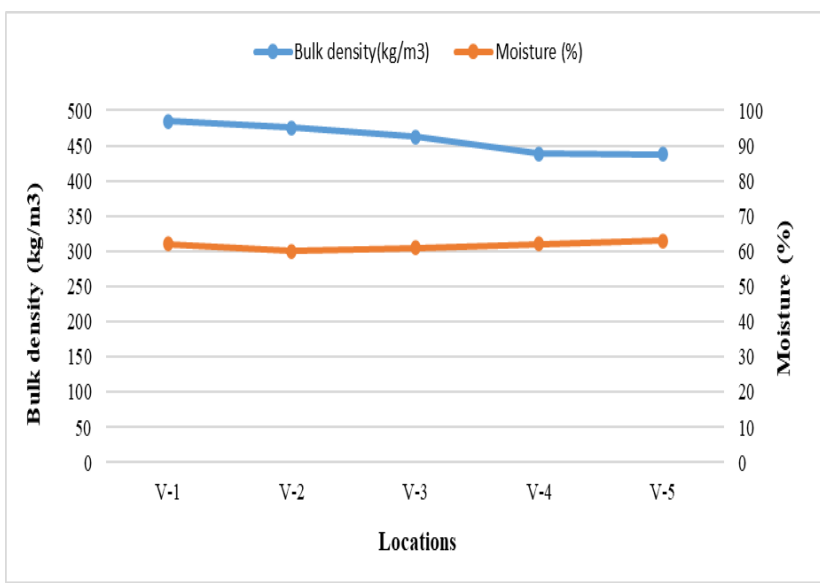

Fig. 2. Bulk density and moisture content of the household waste in villages of district Haridwar.

waste produced in the urban and rural communities (Sharholy et al. 2007). A striking feature is that the composition and density of the generated solid waste vary within the rural areas due to the dissimilarities in topographical, cultural, financial and societal conditions. Ultimate analysis and calorific value of household waste (dry basis): Due to the lesser availability of data related to the characteristics and calorific value of the waste generated in the rural area. Hence, it is difficult to make complete strategies to manage solid waste. So, the ultimate analysis of the solid waste included the testing of carbon, nitrogen, $\mathrm{C} / \mathrm{N}$ ratio, potassium, and phosphorus to assess the potential of waste to be composted. The results of these constituent analysis was based upon the dry weight (after measuring the moisture content) of the samples. The

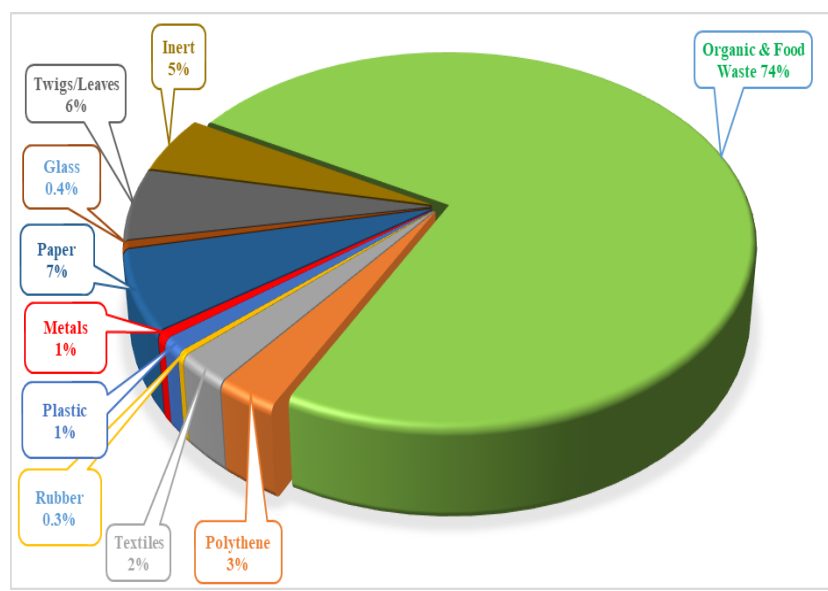

Fig. 3. Average waste composition in the selected villages of district Haridwar.

amount of carbon (13.1 - 14.6\%), nitrogen (1.4 -1.7\%), phosphorus $(0.7-1.0 \%)$, potassium $(0.4-0.6 \%)$, and ash $(10.1-13 \%)$ was measured in the five villages' household organic waste, respectively as shown in Table 4 and Fig. 4. The amount of calorific value of dry organic waste ranged between $900-1009 \mathrm{Kcal} / \mathrm{kg}$ in selected five villages (Fig. 5). Hence, dry waste can be separated and stored for further processing or may be transferred to nearby waste to energy plants.

Challenges and future perspective for solid waste management: Segregation of the waste at the source for analyzing the organic and recyclable portions bids the significant advantage socially, environmentally and economically. Systematic separation of the solid waste program was not practical in the studied villages. Sorting of the metals by the residents was also noted. The 
Table 3. Percentage of household waste composition in each village of district Haridwar.

\begin{tabular}{lllllll}
\hline Component & Unit & V-1 & V-2 & V-3 & V-4 & V-5 \\
\hline Organic \& Food Waste & $\%$ & 79.42 & 78.18 & 70.71 & 72.62 & 69.78 \\
Polythene & $\%$ & 3.14 & 2.25 & 5.45 & 1.53 & 1.74 \\
Textiles & $\%$ & 1.48 & 1.29 & 6.65 & 1.6 & 1.56 \\
Rubber & $\%$ & 0.38 & 0.36 & 0.34 & 0.32 & 0.35 \\
Plastic & $\%$ & 1.27 & 1.2 & 1.14 & 1.09 & 1.03 \\
Metals & $\%$ & 0.66 & 0.58 & 0.81 & 0.51 & 0.45 \\
Paper & $\%$ & 4.57 & 5.83 & 8.44 & 6.14 & 8.42 \\
Glass & $\%$ & 0.68 & 0.75 & 0.66 & 0.58 & 0.37 \\
Twigs/Leaves & $\%$ & 4.39 & 4.33 & 2.86 & 10.64 & 8.57 \\
Inert & $\%$ & 4.05 & 5.28 & 2.95 & 5.04 & 7.73 \\
\hline
\end{tabular}

Table 4. Ultimate analysis of household organic waste in each village of district Haridwar.

\begin{tabular}{llllll}
\hline Component & V-1 & V-2 & V-3 & V-4 & V-5 \\
\hline Carbon (\%) & 13.1 & 14.3 & 14.1 & 14.6 & 14.0 \\
Hydrogen (\%) & 8.3 & 7.7 & 8.0 & 8.4 & 8.3 \\
Oxygen (\%) & 65.8 & 65.0 & 63.4 & 64.0 & 66 \\
Nitrogen (\%) & 1.7 & 1.4 & 1.4 & 1.5 & 1.5 \\
Sulphur (\%) & 0.08 & 0.07 & 0.08 & 0.08 & 0.09 \\
Ash (\%) & 11 & 11.5 & 13 & 11.4 & 10.1 \\
\hline
\end{tabular}

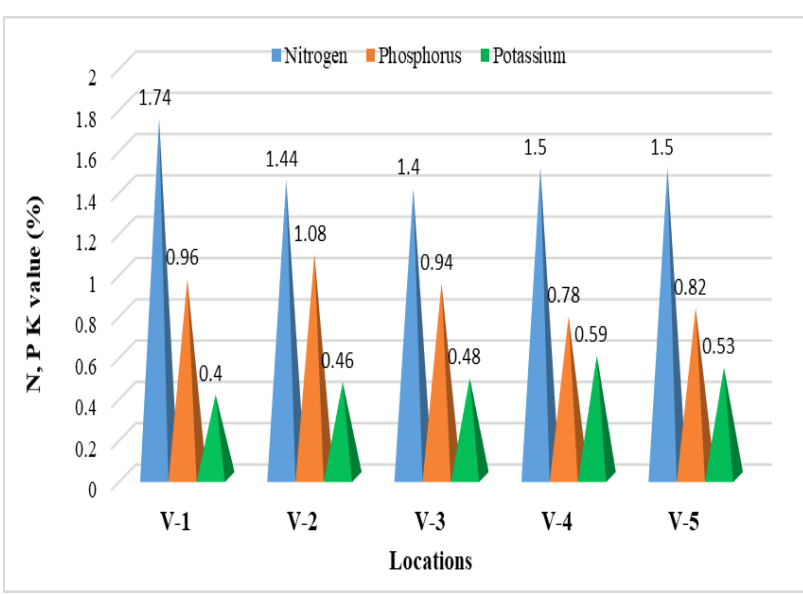

Fig. 4. $N, P, K$ value of household (dry waste basis) generated in the villages of district Haridwar.

villagers were not much aware of the detrimental effects of poor solid waste disposal practices on the environment and health. It was observed that in the studied rural communities, a major portion of the solid waste generated was dumped openly. Open dumping is unaesthetic and unhygienic, which could be a major aspect of public health. To financially and technically manage the waste, the officials of local government like municipality helped the village council or village panchayat. However, the support was not enough for the execution of an integrated solid waste management plan. Therefore, the solid waste generated do-

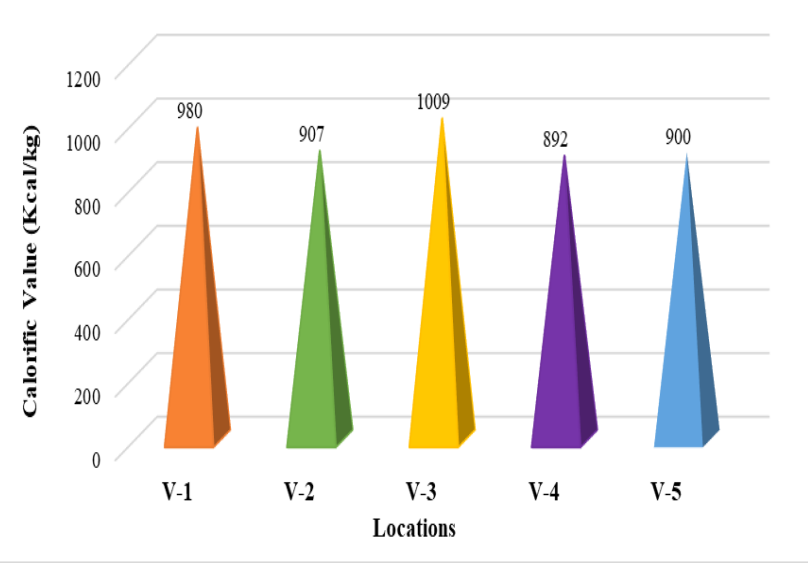

Fig. 5. Calorific value of household (dry waste basis) generated in each village of district Haridwar.

mestically in the villages needs to be classified into organic and inorganic waste for sustainable waste management. The total generated waste could be divided into food waste and can be supplied for livestock as fodder and biodegradable organic waste for farming. Since most of the waste is biodegradable, hence co-composting with cattle waste is recommended. The waste (food waste) can be used for livestock as feed supplied to a livestock farm. The leftovers would be composting separately or in a common composting facility. The recyclable waste could be separated and sold for recycling. The dry waste can be separated 
and stored for further processing and directed to nearby waste to energy plants. The rest of the inorganic waste should be disposed of at the nearby dumping and landfill sites. Hence, a simple model can be applied for solid waste management for the rural communities for its proper utilization (Fig. 6).

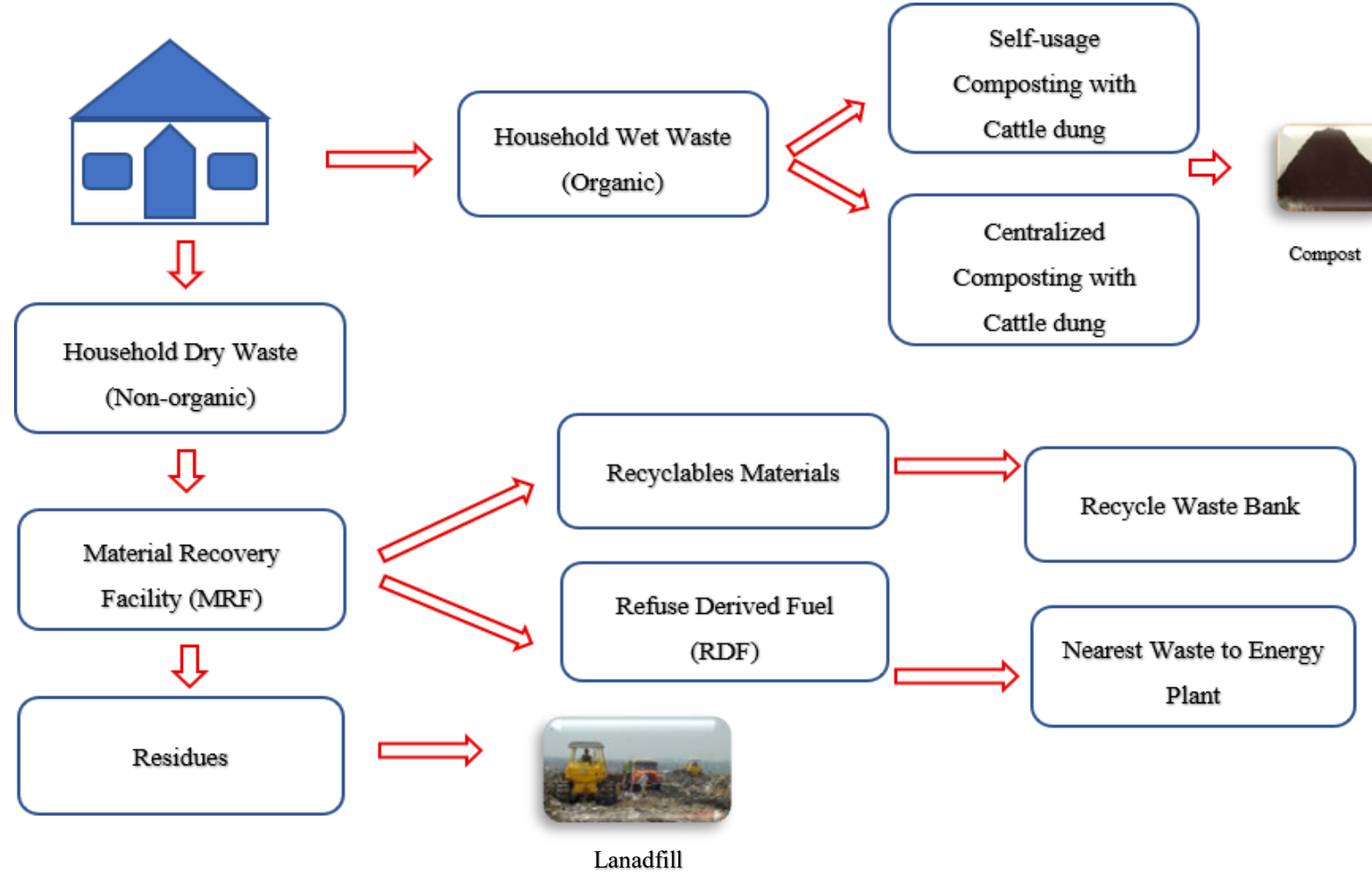

Fig. 6. A simple model for solid waste management for rural areas.

\section{Conclusion}

Based on the observations, more than $90 \%$ of the total generated waste in the villages of District Haridwar was cattle dung, and the rest $5-10 \%$ was household waste containing $70-80 \%$ biodegradable portion. The major waste management problem in rural setup is the lack of source separation and proper disposal strategy as generally. The household waste is dumped outside the houses and across the road. Due to the lack of garbage collection facilities, the majority of rural residents are not following the recommended waste separation and disposal practices. This solid waste produces odour and anaesthetic look and ultimately pollute the river Ganga during the rainy season. Hence, it has to be appropriately managed at the household level by collecting dry and wet waste separately to reduce the public health risk. Composting organic (biodegradable) household waste with animal waste is the best option, which can be used as a fertilizer in agriculture. The dry fraction (nonbiodegradable) can be transferred to waste to energy facilities in nearby areas. General public awareness is a must in the success of any public project for implementing a waste management strategy. The municipality and village panchayat should organize social and environmental awareness programs for rural waste utilization in agriculture. Another requirement is developing better garbage collection facilities, such as garbage storage centers and garbage collection bins, should be designed. The study outcome will help to create the concept of waste management and disposal systems, mainly for rural areas situated along the rivers. Hence, it is concluded that the micro-level characterization of solid waste generated in rural areas is the best suited sustainable waste management solution.

\section{ACKNOWLEDGEMENTS}

The authors acknowledge the scheme under Namami Gange initiated by Govt. of India, New Delhi for initiation and financial support for this study. The authors also wish to express sincere gratitude to all members and villagers who contributed their valuable support to complete this study.

\section{Conflict of interests}

The authors declare that they have no conflict of interests.

\section{REFERENCES}

1. Adeniran, A.E., Nubi, A.T., Adelopo, A.O. (2017). Solid waste generation and characterization in the University of Lagos for a sustainable waste management. Waste Management, 67: 3-10. DOI.org/10.1016/j.wasman.2017.0 5.002 
2. Agamuthu, P., Mehran, S.B. (2019). Sustainable solid waste management: global andasian perspective. In: Rajeev Pratap Singh, Vishal Prasad, Barkha Vaish (Eds.), Recent Advances and Global Challenges in Waste Management, Taylor and Francis group/CRC Press. ISBN 978 -1-138-39042-3.

3. Agamuthu, P., Mehran, S.B. (2020). Waste management challenges in Malaysia. In:Pariatamby, A., Shahul Hamid, F., Bhatti, M.S. (Eds.), Sustainable WasteManagement Challenges in Developing Countries. IGI Global, Hershey, PA, pp.186-222. DOI:10.4018/978-1-7998-0198-6.

4. APHA (2012). Standards methods for the examintion of water and wastewater. Washington, D.C., American public health association, American water works association and water environment federation.

5. Al-Khatib, I.A., Monou, M., Abu Zahra, A.S.F., Shaheen, H.Q., Kassinos, D. (2010). Solid waste characterization, quantification and management practices in developing countries. A case study: Nablus district Palestine. Journal of Environmental Management. 91: 1131 - 1138. DOI: 10.1016/j.jenvman.2010.01.003

6. Bhatia, A., Ali, M., Sahoo,J., Madan, S., Pathania, R., Ahmed, N. and Kazmi, A.A. (2012). Microbial diversity during rotary drum \& windrow pile composting. Journal of Basic Microbiology, 51, 1-11. DOI.org/10.1002/jobm.20 1100077

7. Census of India (2011). Report on Post Enumeration Survey, Registrar General and Census Commissioner, India 2/A, Mansingh Road, New Delhi

8. CPCB (2004). Management of Municipal Solid Waste. Ministry of Environment and Forests \& Climate Change. Central Pollution Control Board (CPCB), New Delhi, India.

9. CPCB (2015). Management of Municipal Solid Waste. Ministry of Environment and Forests \& Climate Change. Central Pollution Control Board (CPCB), New Delhi, India.

10.Das, D., Srinivasu, M., Bandyopadhyay, M. (1998). Solid state acidification of vegetable waste. Indian Journal of Environmental Health. 40 (4) : 333-342.

11.Dorenfeld, E. et al. (2012). Improving solid and human waste management in rural Namibia communities. http:// www.drfn.info/docs/ecap/reports/comp2/ WPI2012_ECAP.pdf

12.Dangi, M.B., Pretz, C. R., Urynowicz, M. A., Gerow, K. G., Reddy, J. M. (2011). Municipal solid waste generation in Kathmandu, Nepal. Journal of Environ Manag., 92(1) : 240-249. DOI: 10.1016/j.jenvman.2010.09.005.

13.El-Messery, M.A., Ismail, G.A., Arafa, A.K. (2009). Evaluation of municipal solid waste management in Egyptian rural areas. Journal of Egypt Public Health Assoc., 84: 51-71.

14.Fahiminia, M., Ansari, M., Nazari, S., Majidi, G., Fahiminia, V., Naseri, S., Mahvi, A., Azimi, A., Yousefi, N. (2014). Survey of solid waste and wastewater separate and combined management strategies in rural areas of Iran. Iranian Journal of Health Sciences 2(4):27-35. DOI: 10.18869/ acadpub.jhs.2.4.27

15.González, P. T., Vega, C. A., Virgen, Q. A., Benítez, S. O. (2010). Household solid waste characteristic and management in rural communities. Journal of Open Waste Management, 3, 167-173. DOI: 10.2174/18759343010030101 67.

16.Mohammadi, A. I. (2012). A survey on the rural solid wastes characteristics in North Iran (Babol). University. Journal of Environmental Research Technology. 2(3): 149 $-153$.

17. Ogwueleka, T.C. (2013). Survey of household waste composition and quantities in Abuja, Nigeria. Resource Conservation Recycle .77: 52-60. doi.org/10.1016/j.res conrec.2013.05.011.

18.Peavy, H.S., Rawe, D.R., Tchobanoglous, G. (1985). Environmental Engineering McGraw-Hill Book Company, Singapore.

19.Rajpal A., Bhatia A., Sudipti A., Kumar T. Kazmi A.A. Chopra A.K. (2014) "Co-treatment of organic fraction of municipal solid waste (OFMSW) and Sewage by Vermireactor" Ecological Engineering. 73 : 154-161. DOI:10.1016/ j.ecoleng.2014.09.012

20.Shah, R., Sharma, U.S., Tiwari, A. (2012). Sustainable solid waste management in rural areas. Int J. Theor Appl Sci, 4(2): 72-75.

21.Sharholy, M., Ahmad, K., Vaishya, R.C., Gupta, R.D. (2007), "Municipal solid waste characteristics and management in Allahabad, India", Journal of Waste Management, 27 (4): pp. 490ロ6. DOI: 10.1016/ j.wasman.2006.03.001

22.Tchobanoglous G, Kreith F. (2002). Handbook of solid waste management. McGraw-Hill, New York.

23.Ugwu, C. O., Ozoegwu, C. G., Ozor, P.A. (2020). Solid waste quantification and characterization in university of Nigeria, Nsukka campus, and recommendations for sustainable management. Doi.org/10.1016/j.heliyon.2020.e04 255.

24.World Bank Data Report (2015). Population estimates and projections- Rural population (\% total population) India. http://data.worldbank.org/indicator/SP.RUR.TOTL.Z S?locations $=\mathrm{IN}$ 